\section{Strategic survey grinding to halt}

GEOLOGICAL surveying of Britain by the British Geological Survey (BGS) has almost ground to a halt this year. Because of over-dependence on short-term contracts and the cost of its recent centralization at a site in Keyworth, Nottinghamshire, strategic surveys of land are running at only 30 per cent of last year's activity.

At the same time, BGS seems to have lost its old friends. Private industry is complaining about its function and performance, BGS has no long-term commitment from government departments that use its services and, unlike most national surveys, it has no direct responsibility to a government minister for strategic surveys and information management. With its parent body, the Natural Environment Research Council (NERC), itself under severe financial pressure, BGS has an uncertain future.

The decline of the land survey activities comes at a bad time. Since 1835 , BGS and its predecessors have been preparing geological maps of the United Kingdom at $1: 50,000$ scale ( 1 inch to 1 mile), with more detailed mapping following later. Although most of the United Kingdom has been mapped at 1:50,000, at least 25 per cent of the maps are obsolete, according to BGS. Moreover, at the more detailed 1:10,000 scale, large areas of the country remain unmapped, partly because of concentration on regions important for economic or development reasons.

After the survey was attached to the newly-formed NERC, in 1965, it accumulated a wide range of new responsibilities: overseas activities, geochemistry, geophysics, seismology, geomagnetism, mineral and water resources. When, in 1973, the Rothschild "customer-contractor" principle was accepted by the British Government, a portion of BGS funds were transferred to government departments. By 1979, the land survey activites were financed and controlled by a consortium -60 per cent NERC, 30 per cent Department of Environment, 5 per cent Department of Trade and Industry, 5 per cent Department of Energy. Meanwhile, other parts of the survey were so heavily engaged on commissioned work that three quarters of the survey's funds came from the customer departments.

Although cutbacks by government departments began in 1980, the first major blow to the land survey was struck in 1982 when the Department of the Environment withdrew from the consortium as well as from other activities, replacing that commitment by a series of short-term (six months) contracts whose allocations were not made until after the start of the financial year. The Department of Energy, meanwhile, transferred its consortium support to deep geological research related to onshore hydrocarbons assessment.
These developments left the land survey almost entirely dependent on NERC. The latest blow, earlier this year, was a cut by NERC in BGS science funds of $£ 1$ million (about 10 per cent) made necessary because of NERC's severe financial shortage. Because short-term BGS commissioned contracts draw on this science budget, and because the recent move to Keyworth has entailed relocation expenses, the result has been a 70 per cent decrease in the funds available for scientific work. Now, routine activities 'such as geomagnetic monitoring

\begin{tabular}{lrrr}
\hline \multicolumn{4}{c}{ BGS budget $£$ million 1984-85 prices } \\
& 1982 & 1983 & 1984 \\
& -83 & -84 & -85 \\
& & & \\
NERC Science Vote & 63.1 & 65.1 & 65.9 \\
Commissioned income & 30.8 & 26.4 & 23.7 \\
BGS Science Vote & & & \\
Commissioned & 9.8 & 10.4 & 9.2 \\
& 18.5 & 16.9 & 14.9
\end{tabular}

BGS Staff numbers:

1973: 757 1979: $1,156 \quad 1985$ Target: 920

are threatened while the land survey programme has been curtailed to 30 per cent of last year's when, according to the director of BGS, Professor Malcolm Brown, this programme needed to be doubled.

There are those, inside and outside BGS, who conclude from this catalogue of misfortune that the Rothschild system was the biggest disaster to hit the survey since its foundation. There are others who say that BGS's problems are more fundamental.

Perhaps the strongest criticisms come from local government and private industry, which charge that the survey is simply not providing an adequate supply of basic geological information needed for planning purposes, for example. And the move to Keyworth will exacerbate the situation, the critics say, by rendering the available information less accessible. But BGS intends to maintain its London library until 1986 at least, and thereafter to maintain a London information centre with two BGS scientists and a duplicate supply of key geological maps and reports.

Many of the private companies are deeply irked that, as they maintain, BGS is in effect a state-subsidized competitor for short-term contracts which is too heavily engaged in such work to provide British industry with basic services. It is hard to document the charge, but staff at BGS concede that customers will tend to benefit from the large infrastructure available to support contracts placed with BGS.

Staff at BGS are all too aware of the backlog in the publication of maps and memoranda. One explanation is the diversion of resources and funds to other activities. It is estimated that one map at $1: 50,000$ scale now requires anything up to $£ 1$ million to produce from scratch. In fact, the survey has about 50 geological memoirs in preparation, some of which might be published for as little as $£ 20,000$, but the money cannot be found.

Another contributory factor, put forward by a visiting group commissioned by NERC to assess BGS, is that while the collapse of the land survey consortium was much to blame, BGS administration of the preparation of reports and maps was inadequate - a charge also made by the previous visiting group a few years earlier. A long-term response to such criticisms, but one of BGS's top priorities, is the establishment of a national computerized database - a massive task, particularly now that strategic surveys use geophysical as well as geological techniques to prepare maps.

Complaints against BGS are offset by industry's acknowledgement of the value of services such as the provision of minerals intelligence and general commodity expertise. In 1981, minerals and quarrying (including oil) accounted for 18 per cent of UK production, and BGS supplies information ranging from distributions of potash horizons based on North Sea drilling to details of small barytes mines.

Ultimate - and, in many people's opinion, excessive - control of BGS rests with NERC. Academic geologists and those working for other national surveys are surprised, even outraged that the director of BGS has to refer to NERC headquarters each new appointment to his staff, for instance. Similarly, every decision relating to the purchase of computing equipment is referred to NERC's central division. Coincidentally, computing problems have been highlighted by a decision by the Department of Energy to cancel its contract with NERC for computing services associated with its continental shelf programme, and by a recent internal NERC report which recommended some decentralization of computing power.

NERC says its control of manpower, budget and the scientific programme of BGS stems from its accountability to Parliament. But NERC is aware of the backlog in the preparation of maps and memoranda, and has proposed that resources might be diverted within BGS for the work.

In short, there is general agreement that the function of BGS which is most in demand - the provision of basic information about the geology and natural resources of the United Kingdom - has, for a number of reasons, virtually fallen by the wayside. Some members of other national surveys suggest that BGS should be wrested from NERC and made responsible to a "minister for natural resources". As no such post exists in the United Kingdom at present, this radical proposal is unlikely to be realized, at least unless NERC itself is disbanded. Given the tight budgets within which BGS is operating, however, it is hard to see that a simple redistribution of its internal resources can have a significant impact on a central problem.

Philip Campbell \& Peter Gambles 